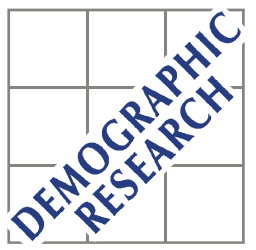

Demographic Research a free, expedited, online journal of peer-reviewed research and commentary in the population sciences published by the Max Planck Institute for Demographic Research Konrad-Zuse Str. 1, D-18057 Rostock · GERMANY www.demographic-research.org

DEMOGRAPHIC RESEARCH

VOLUME 11, ARTICLE 6, PAGES 149-172

PUBLISHED 14 September 2004

www.demographic-research.org/Volumes/Vol11/6/

DOI: 10.4054/DemRes.2004.11.6

Research Article

\title{
Is marriage loosing its centrality in Italy?
}

\section{Alessandro Rosina \\ Romina Fraboni}

(C) 2004 Max-Planck-Gesellschaft. 


\section{Table of Contents}

1 Introduction 150

2 The crucial role of marriage in Italy 151

3 A hypothesis to explain the delay in the diffusion of 154 cohabitation in Italy

$4 \quad$ Some empirical results 156

4.1 Data sources 156

$\begin{array}{lll}4.2 & \text { Opinions and behaviours } & 156\end{array}$

5 Discussion 162

6 Acknowledgements 163

$\begin{array}{ll}\text { Notes } & 164\end{array}$

$\begin{array}{ll}\text { References } & 167\end{array}$ 
Research Article

\title{
Is marriage losing its centrality in Italy?
}

\author{
Alessandro Rosina ${ }^{1}$ \\ Romina Fraboni $^{2}$
}

\begin{abstract}
Unlike the countries of north-western Europe, marriage in Italy has maintained a crucial role in the process of family formation. This raise doubts about the possibility that the theory of "second demographic transition" could adequately account for the behaviour of the European population living south of the Alps. The aim of this paper is twofold: to provide some empirical evidence that cohabitation is now spreading in Italy; and to propose an explanation of the delay of its diffusion until the 1990s. The hypothesis proposed here explains the delay, not so much in terms of limited interest of the Italian youth towards this type of union, but with the convenience of the children in the Mediterranean area to avoid choices which are openly clashing with the values of parents.
\end{abstract}

Istituto di Studi su Popolazione e Territorio, Università Cattolica, Largo Gemelli 1, 20123, Milano, Tel.+3902 72343883, E-mail: alessandro.rosina@unicatt.it

2 Istituto Nazionale di Statistica (ISTAT), Via Ravà 150, 00142 - Roma, Tel. +39 0659524605 ,

E-mail: fraboni@istat.it 


\section{Introduction}

The spread of unmarried cohabitation as a type of first union, and having children out of wedlock, is perhaps one of the most remarkable social transformations which has taken place in past decades. "These developments raise questions about the hegemony of legal marriage as the basis of family life and many of the assumptions on which public policies are built" (Kiernan 2002a).

In Western countries, at least until the early 1960s, marriage was a prerequisite for a couple to live together and have children. Today, in north-west Europe, cohabitation has become an accepted alternative to marriage (Hoem 1995, Toulemon 1997, Liefbroer 2003). In central Europe too, this behaviour has become widespread among the youth, even though informal unions are often transformed into marriage when a couple starts having children (Liefbroer 1999, Mills 2000, Pinnelli et al. 2002).

During the 1980s, cohabitation was the preferred choice for the formation of a first union among the youth of the whole of Western Europe. Nevertheless, at that time, the centrality of marriage seemed to have had in the Alps its natural defence (Castiglioni and Dalla Zuanna 1994, Lesthaeghe, Moors 2000, Surkyn and Lesthaeghe 2002).

This has led several authors to support the hypothesis that such behaviour is not consistent with the Italian socio-cultural context (among others: Brienza 2001, Nazio and Blossfled 2003). On the other hand, according to other authors, Italy would be a late-comer. Following the theory of the Second Demographic Transition "all countries go through the same sequence" (Van de Kaa 1987). For Lesthaeghe (1995, see also Prinz 1995), in the mid-1990s Mediterranean countries were still at the beginning of the second phase of family change - therefore late, if compared to other western countries. Following what has already been observed in the Scandinavian countries, Italy too, would as a consequence be bound sooner or later to a questioning of marriage through a wide-ranging diffusion of informal unions and extramarital births.

Between these two opposite scenarios, our belief is that a third one is more likely. Cohabitation is also spreading in Italy but without a questioning of the conjugal basis of family, and more importantly, in continuity with some strong peculiarities of the Mediterranean family pattern.

The aim of this paper is twofold: to provide some empirical evidence that cohabitation is spreading in Italy; and, strictly connected to the first aim, to propose an explanation of the delay of its diffusion until the '90s.

In the next section, we shall describe the differences in the process of questioning marriage between Italy and other western European countries. In the third section we shall introduce our hypothesis regarding the delay in the diffusion of informal unions. In the fourth section we shall provide some empirical evidence that a process of diffusion is underway among the youngest generations. We shall illustrate how this is 
consistent with our hypothesis. In the last section we shall provide some concluding remarks.

\section{The crucial role of marriage in Italy}

After having reached particularly high levels in the first half of the 1960s, the period indicators for first nuptiality in Europe began a clear-cut process of decrease, which turned into real collapse in the Scandinavian countries. This trend was followed by other western European countries, although with different timing. Diverse theories have been proposed in order to account for this decreased inclination to get married which is reflected in the progressive postponement of the age at marriage and in an increase in people intentionally renouncing the conjugal union. In the literature, there are two theories which have drawn the most attention: the New Home Economics (Becker 1981); and the Second Demographic Transition (van de Kaa 1987, Lesthaeghe 1995).

According to Becker's theory, the key variables are the increase in the levels of education and in work opportunities for women. Their increased autonomy and cultural and economic independence have reduced their material convenience in getting married. The economic wealth which they can attain by investing in themselves and their career is far greater than in their roles as wife and mother.

While Becker stresses the economic rationality to account for the recent sociodemographic behaviour, the theory of the Second Demographic Transition (SDT) tends to favour the role of the ideational changes. For the supporters of this latter theory, the progressive increase in individual autonomy in the ethical, religious and political spheres is at the basis of the changes in family formation. Secularism, the emancipation movements, the spread of post-materialist values (such as personal development and self-fulfilment), the scepticism towards institutions, and the increased impatience towards external interference in one's own life (particularly from any form of authority) are all aspects of a transformation in values which have lead the individual to choose according to his own free will which is the most adequate way to live his own life.

The decrease in marriages and the increase in informal unions can therefore be seen, at least at first, as an expression of a non-conformist attitude, of protest against authority, a way of manifesting one's own freedom against conventions. The forerunners of the new behaviour would therefore be the more educated youth, the more secularized, the more autonomous, and consequently, also the more demanding, in terms of wanting some minimum conditions of quality in their affective relationship. Premarital cohabitation would act as a trial period for the assessment of the partner's characteristics and of compatibility with one's needs and objectives for self-fulfilment. 
Besides being less and less disposed to limit their own freedom, younger generations would also be more and more restless in adopting behaviours that would entail assuming commitments and responsibilities. Consequently, they tend to avoid those choices which are perceived as irreversible, or too binding. It is important to underline that the minor economic convenience that more educated women find in marriage is not refuted by the SDT theory. What is disputed is that this reason is by itself sufficient to explain the new behaviour.

To which extent can these theories - mainly developed in reference to the social transformations underway in north-west Europe - explain and anticipate family behaviours in the countries of Southern Europe? The concept of the SDT "suggests that European countries experience one common transition process. This implies that differences across European countries are temporary" (De Beer et al. 2000). This is in contrast with the fact that "the last ten years appear to have been a period of persistent cross-country differences in cohabitation and extra-marital fertility patterns. By the late 1980s a large gap opened in Western Europe along the north-south axis in the propensity to choose consensual unions rather than marriage at first union and in proportions of children born to unwed mothers" (Macura et al unedited draft). In fact, unlike other western countries, marriage in Italy (and generally in Mediterranean Europe) - although postponed at a progressively older age - seems however to still have a crucial role at least as far as three fundamental aspects are concerned: leaving the parental home; union formation; and reproduction. There is a high synchronisation between leaving the parental home and marriage. More than $80 \%$ of Italian women born in the 1960s leave the family of origin directly to get married (Ongaro 2001), whereas this percentage is lower than $40 \%$ in the other western countries (Kiernan 2002a). Marriage is still the event that sanctions the beginning of life together for a young couple: more than $85 \%$ of first unions are marriages. In north-west Europe, for the majority of the youth the beginning of first partnership takes place without the conjugal bond (Figure. 1). Whereas, in Italy, even more than in some other Catholic countries, marriage remains the place to become parents (Table 1). Finally, even in the opinions of the younger Italian generations, both family and marriage continue to be considered among the fundamental values: more than $85 \%$ of young people (aged 18-24 years) declare that marriage is not an outdated institution, and that in the future more attention should be given to the family (De Sandre 2000, Gubert 2000, Buzzi et al. 2002). Such a high percentage of consent towards marriage has hardly any equal, not only in western countries but also in the countries of Eastern Europe (Surkyn and Lesthaeghe 2002).

There does not seem therefore, on the basis of the picture portrayed by the data here included, to be much space in Italy for a revolution in the ways of union and family formation. Yet, as we shall see in the next sections, under this apparent surface 
characterised by a strong sense of tradition and immobility, some important changes are taking place.

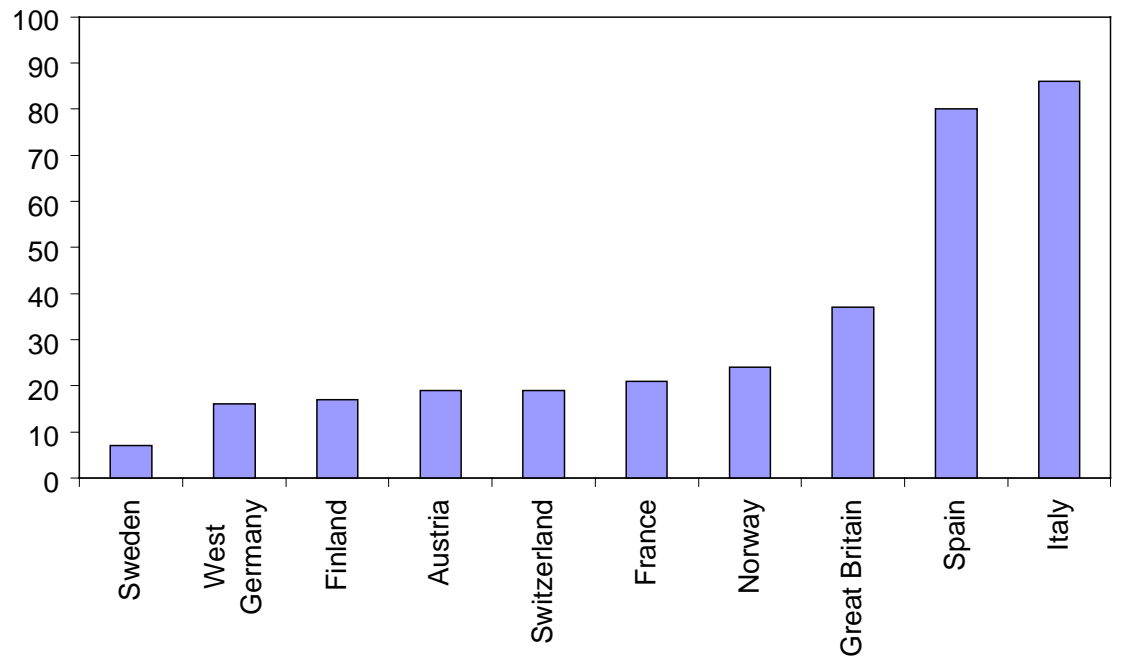

Figure 1: Percentage of direct marriage of women in first partnership (25-29 years old).

Source: Fertility and Family Survey project (conducted between 1988-1999).

Table 1: $\quad$ Partnership status at first birth. Women aged 25-29 (at interview).Row percentage

\begin{tabular}{llll}
\hline & married & consensual union & not in any partnership \\
\hline Austria & 50.3 & 24.6 & 25.1 \\
Belgium & 91.1 & 5.2 & 3.7 \\
France & 59.9 & 28.1 & 12.0 \\
West Germany & 63.4 & 9.1 & 27.5 \\
Netherlands & 83.0 & 11.0 & 6.0 \\
Norway & 61.3 & 25.5 & 13.2 \\
Spain & 87.9 & 5.3 & 6.8 \\
Italy & 90.8 & $\mathbf{4 . 3}$ & $\mathbf{4 . 9}$ \\
\hline
\end{tabular}

Source: Fertility and Family Survey project (conducted between 1988-1999). 


\section{A hypothesis to explain the delay in the diffusion of cohabitation in Italy}

Explanations accounting for the differences between the Italian behaviour and that of north-west Europe with a simple delay on an already open path are, to say the least, incomplete, because they do not consider the cultural specificities of the Italian society.

Our hypothesis (see also Rosina 2001) is based on the belief that the lack of a diffusion of cohabitation in Italy is not so much due to the low level of secularisation and the strong role of the Catholic Church, but mainly to the strong ties between parents and children, anthropologically rooted in the Italian society (Reher 1998, Micheli, 2000, Dalla Zuanna 2001).

This strong relationship, common to other countries of the Mediterranean area such as Spain, expresses itself, among other things, through: support by the parental family of the young adult, not only up to the age of consent, but also until he/she has reached a satisfying employment position (Sgritta 2002; Rosina et al. 2003; Moreno Minguez 2003); substantial help while he/she is getting married, in particular (but not only) for the purchase of a house (Holdsworth and Irazoqui Solda 2002, Barbagli et al. 2003); marked residential proximity between parents and married children; and continuous help by the parents to their children even after they are married (Barbagli 1996, Tomassini et al. 2003).

Several historical studies have shown how all these aspects, that can clearly be seen in today's Italian society, have profound roots in the past (Reher 1998, Derosas 2002, Viazzo 2003). Even when the neolocal model was prevailing, children tended to leave the parental family only when they were capable of forming their own family. And even then, married children usually established their residence close to their parents. The relationship of mutual help thus continued to be intense and stable throughout the course of their life. Where the patrilocal model was in force, the phenomenon of nuclearisation in the second after war period brought about a definite decrease of co-residence between parents and married children. But this has been transformed into a strong residential proximity, which has no equal in any other western country (Barbagli et al.2003).

In today's Italian society all these aspects are reinforced by a substantial lack of a welfare system capable of supporting the youth in the crucial events of their life (Note 1), which is at the same time cause and effect of the crucial role of the family in Italian society (Saraceno 1994; De Sandre 1997).

According to our hypothesis, the marked material and affective investment which is at the basis of the strong family ties feeds and reinforces the intense emotional involvement of the parents in the life of their children. So much so that parents tend to 
see their children almost as their own extension, to the point that they consider the failures of their children as their own defeats (Dalla Zuanna 2001). This leads them to adopt a particularly protective attitude towards their children, with which they tend to guide their children's choices with a view of avoiding behaviour that they do not approve of.

The prolonged permanence in the parental family, the residential proximity, and the continuous and intense relationship, even after the exit from the parental family, do not favour, in Mediterranean countries, the development of that "tolerant indifference" among generations which enables the European youth in the weak family ties area to freely make choices, even though these are not shared by their parents (Beck 1997). Strong proximity requires some sort of complicity. Italian parents can't pretend to ignore the behaviour of their children living in the same residential context and with which they have a continuous material and immaterial interchange. In the case of socially unacceptable behaviour by their children, parents are forced to take a stance. Keeping an intense relationship virtually means approval. As a consequence, parents tend to discourage their children from behaviour they do not approve with affective and material means at their disposal. On the other hand, the strategic importance of the parent's support makes it particularly disadvantageous for young Italians to make choices which parents do not approve of, and that could render their help less generous (Note 2).

Consequently, the choice to cohabit can be carried out without painful breakingoffs (which otherwise would confine it to minority behaviour) only if it does not clash irremediably with the values of the parents (and of their context of reference). That is, if the parents are culturally open minded to the possibility that their children can make non traditional choices.

If this is true we expect young people to have had a generally favourable opinion of cohabitation for a while now, and low diffusion of informal unions to be connected with a limited opening-up of society. As to the behaviour, forerunners may belong to less traditional contexts (big cities in the North) and to family with greater cultural resources (parents with higher education). In particular, the father's education is important, as people with a higher education tend to be more open minded toward the possibility of their children making non traditional choices. They have better cultural and material resources, enabling them to be less subjected to the conditioning of social norms. Forerunners usually belong to the population with high cultural status. This is also true for leaving the parental home for reasons of independence and for non traditional family formation (Goldscheider and Goldscheider 1999). With regards to the diffusion of cohabitation in Italy, not only the educational level of the youth, but, net of this, also the educational level of the parents would be significant. In fact, according to our hypothesis, the diffusion of cohabitation among the young generations 
must be preceded by a process of acceptability of this behaviour among the generations of the parents.

\section{Some empirical results}

\subsection{Data sources}

The sources for our data are the following three surveys. The first one is the IARD survey (Buzzi et al. 2002). This Italian survey enables an evaluation of attitudes and opinions over time. It is composed of a nationally representative sample of 3,000 youth between 15 and 34 years old. This is a survey that is regularly carried out every 4-5 years. The first survey took place in 1983, the last one was in 2000 (Note 3).

The most recent and important Italian survey on socio-demographic behaviour is the nationally representative survey "Family, Social Subjects and Childhood" (FSSC98) carried out in 1998 by ISTAT (National Statistical Institute). A wide variety of topics are covered in the survey, including retrospective questions about leaving the parental home, marriage and family formation. The survey has a huge sample size of about 24,000 households, amounting to about 60,000 individuals (Istat 2000).

More recently, another survey on the topic of family formation has become available. The "Survey on Family Behaviour in Urban Context" (SFBUC02) was conducted in 2002 in five Italian cities: Padua and Udine in the North; Florence and Pesaro in the Centre; and Messina in the South. The sample is composed of about 2,500 women with at least a child (Breschi, Livi Bacci 2003). This survey is therefore more limited than the ISTAT survey. However, it provides more detailed information on cohabitation.

\subsection{Opinions and behaviours}

It is interesting to note that in Italy among the youth of the 1980s there was already a favourable opinion towards cohabitation. More importantly, many of them (two out of three) were already ready to carry it out (Table 2). If this opening-up in opinions would have been matched by a practical implementation of this behaviour, the diffusion of cohabitation would have been in Italy, already at the start of the 1980s, at an advanced point - in line with the other western European countries - meeting therefore, in the predicted timing, the stages of the Second Demographic Transition as described by Lesthaeghe (1995). 
This didn't happen, not because the youth were not ready, but because parents were not ready. Up to the mid 1990s, youth declared to perceive that the society they were living in kept on considering it as deviant behaviour when a young couple was living together without being married (Table 2, last row).

Table 2.: $\quad$ Attitudes of youth (15-24 year of age) towards cohabitation (\%)

\begin{tabular}{|c|c|c|c|c|c|}
\hline Year of survey & 1983 & 1987 & 1992 & 1996 & 2000 \\
\hline Generation & ‘59-68 & '63-72 & $68-77$ & $72-81$ & '76-85 \\
\hline $\begin{array}{l}\text { Generation of the parents } \\
\text { (approximate) }\end{array}$ & '29-38 & '33-42 & ‘38-47 & $42-51$ & $46-55$ \\
\hline Approves cohabitation & 76 & 79 & 78 & 84 & 87 \\
\hline Doesn't rule out cohabitation & 65 & 65 & 66 & 73 & 80 \\
\hline $\begin{array}{l}\text { Thinks cohabitation is not approved } \\
\text { by society }\end{array}$ & 64 & 62 & 57 & 53 & 34 \\
\hline
\end{tabular}

Source: lard survey, several years (Buzzi et al. 2002; Barbagli et al. 2003)

The cultural opening-up of society becomes noticeable mainly after the mid-1990s (Table 2, last row). Indeed, in the last survey (2000) two out of three young Italians declared to not perceive any objection to their possible choice of cohabitation in the context in which they lived. We would like to remark that the young people at the end of the 1990s are the children (born during the 1970s) of the generation that had introjected the cultural changes of the 1960s (Note 4). This generation was born around the first after war decade and were therefore around 18 years old in 1968. It is the same generation of those northern Europeans who were beginning to experiment with alternative unions to marriage. The fact that the cultural opening up of Italian parents starts to be widespread from this very generation is consistent with our hypothesis. If indeed in the area of weak family ties, the very generation that develops the opening-up towards a new behaviour can right away engage in it, in the area of strong ties, by contrast, a process of diffusion of acceptance of such behaviour among the parents is a necessary preliminary to the process of diffusion among the children (Note 5). The strong influence of the parents has hindered the implementation of a non traditional behaviour by those who were entering their adult life at the end of the 1960s, but it certainly could not prevent the diffusion, from that generation onwards, of a positive attitude toward such a choice. Consequently, the children of this generation are favoured by such a cultural opening up (Note 6). These are the children who were at the onset of their adult life at the end of the 1990s.

Let's now consider the behaviour. We are particularly interested in evaluating if, consistent with our hypothesis, there are signs of a diffusion process underway, and if, 
for the forerunners, the parents' characteristics are also relevant, besides those of the youth (in particular the level of education of the father).

We shall use the data of the "Family, Social Subjects and Childhood" (FSSC98) survey carried out in 1998 by ISTAT (National Statistical Institute). This provides the most recent nationally representative data available on family formation in Italy. It gives us some detailed information on the time and reasons for leaving the parental home and on the history of marital unions. But, it does not inform us on cohabitation as a first union not followed by marriage. Since a very large majority of Italian informal unions are a sort of prelude period to marriage (Sabbadini 1991, Rosina 2002), the limitation of the study to pre-marital cohabitation is only slightly partial (Note 7). It is also possible to evaluate the incidence of cohabitation as reason for leaving the parental home.

By using this last information we can see that the incidence of informal unions remains very low until the birth cohorts of the 1950s. In the South this behaviour remains at a marginal level even with successive generations, and is almost exclusively due to the phenomenon of the "fuitine" (Note 8) (Sabbadini 1991). In the North-centre, on the other hand, the process of diffusion appears to be coming out of its latent phase. This is particularly true in the big cities. But also in medium and smaller towns the choice of starting a first union is becoming socially visible (Figure. 2).

Focusing now on pre-marital unions in the North-centre, we can see that the choice to cohabit is not only affected by the level of education of the youth but also by the level of the father. Among the young women with a university degree, cohabitation is a much more common choice among those coming from a family with higher cultural resources (Figure. 3).

The descriptive results we have just seen are confirmed by a multiple regression analysis (Table 3). We use a binomial logistic model to analyse the probability of a cohabitation before marriage. In order to avoid too truncated cohorts, we restrict our analysis to married women of at least 35 years of age at the time of the survey (3681 observations, 267 premarital cohabitations). 


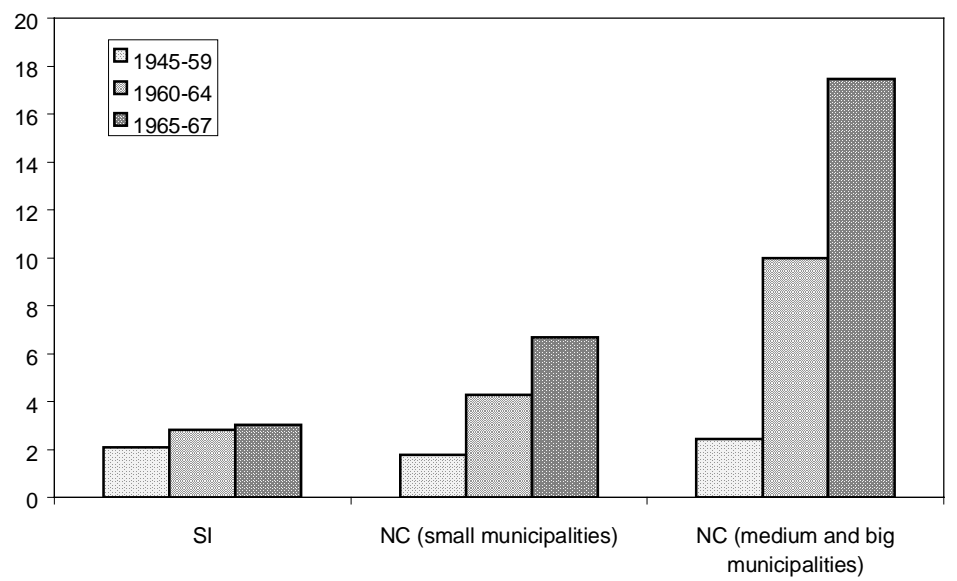

Figure 2: $\quad$ Percentage of women leaving the parental home for cohabitation among women leaving to form a first union before 30 years old. North-Centre (NC) and South-Islands (SI). (FSSI98 data)

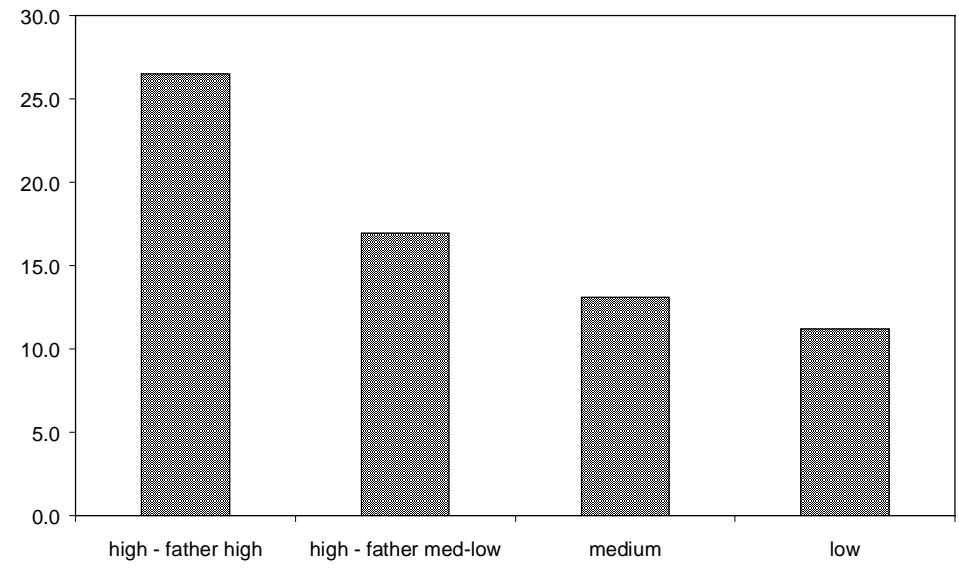

Figure 3: $\quad$ Percentage of premarital cohabitation by level of education of the women and their fathers. North-Centre. Cohort 1960-67. (FSSI98 data)

Source: Rosina et al (2003) 
Table 3: $\quad$ Results of the logistic regression model on the probability of cohabitation before marriage. Women of the North-centre married before 35 years old (FSSI98 data).

\begin{tabular}{|c|c|c|c|}
\hline Variable & Coeff. & & (se) \\
\hline \multicolumn{4}{|l|}{ Cohort } \\
\hline $1950-54$ & -0.99 & ** & $(0.18)$ \\
\hline $1955-59$ & -0.31 & ** & $(0.14)$ \\
\hline 1960-62 & 0 & & - \\
\hline \multicolumn{4}{|l|}{ Level of Education } \\
\hline Compulsory & -0.07 & & $(0.25)$ \\
\hline High-school & -0.08 & & $(0.14)$ \\
\hline University & 0 & & - \\
\hline \multicolumn{4}{|l|}{ Education of the father } \\
\hline Only primary school & 0 & & - \\
\hline Compulsory school & 0.49 & ** & $(0.18)$ \\
\hline High-school and above & 0.68 & ** & $(0.19)$ \\
\hline \multicolumn{4}{|l|}{ City size } \\
\hline Metropolitan centre & 0.47 & ** & $(0.19)$ \\
\hline Suburbs, metropolitan area & -0.05 & & $(0.24)$ \\
\hline Up to 10 thousands inhabitants & -0.20 & * & $(0.15)$ \\
\hline Above 10 thousands inhabitants & 0 & & - \\
\hline Intercept & -2.34 & ** & $(0.15)$ \\
\hline
\end{tabular}

$p$-value $<0.10 ;{ }^{* *} p$-value $<0.05$.

The cohort effect is significant, and confirms a progressive diffusion of the phenomenon among younger generations. But we would like above all to remark that the level of education of the father is strongly significant net of the level of education of the woman herself and net of the generation to which she belongs and the place of residence. People with a higher education are less subjected to the conditioning of social norms and tend to be more open minded toward the possibility of their children making non traditional choices (Note 9).

A similar analysis can be carried out on the most recent data of the "Survey on family behaviour in urban context" (SFBUC02) conducted in 2002 in five Italian cities on a sample of about 2,500 women with at least a child. This survey is therefore more limited. However, it provides more detailed information on cohabitation than the 1998 ISTAT survey. Specifically, it is possible to build a richer model thanks to the 
availability of some information on the partner at first union and on religiosity at 25 years old.

Here too we use a binomial logistic model to analyse the probability of cohabitation before marriage. In order to avoid too truncated cohorts, the analysis is restricted to married women of at least 39 years of age at the time of the survey (2424 observations, 350 premarital cohabitations), therefore the cohorts from 1950 to 1962 (the same of the previous analysis on the ISTAT data). The covariates being used are: educational level and religious attendance for both the partners, type of employment of the woman at first union, educational level of the woman's parents, and geographical context (Rosina and Billari 2003). It is therefore important to underline that here too, controlling for all these covariates, the effect of the level of education of the father is confirmed to be strong and significant on the probability of a consensual union (Figure. 4), whereas the educational levels of the mother and of the partner do not prove to be significant.

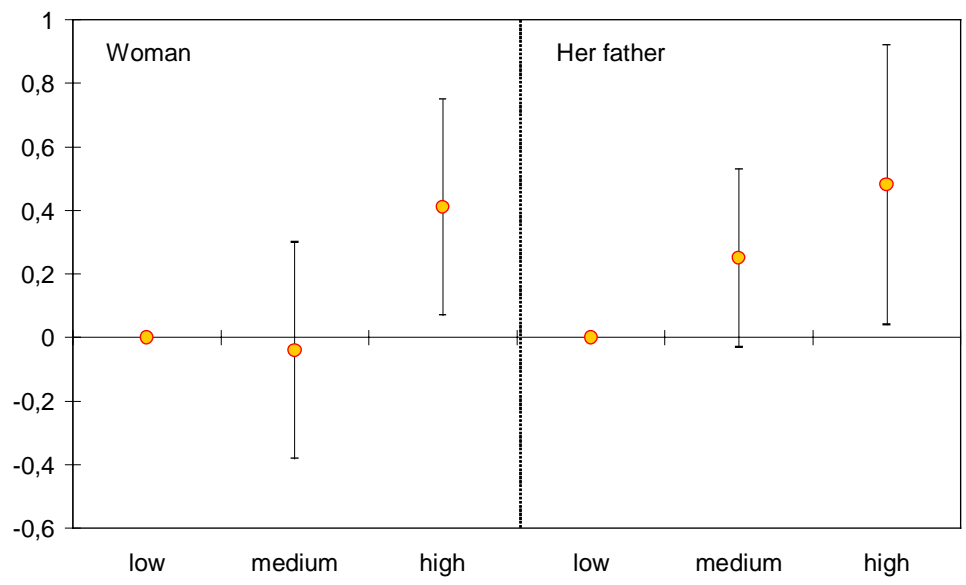

Figure 4: Level of education of the woman and her father. Effects (and 95\% confidence interval) estimated from a logistic model on the probability of cohabitation before marriage. Women in urban context married before 39 years old (SFBUCO2 data).

Source: Our elaboration from Rosina and Billari (2003).

$\wedge$ Net of religious attendance by the woman and the partner; the type of first employment of the woman; level of education of the partner and of the mother; and geographical context. 


\section{Discussion}

The data here presented provide empirical evidence that the process of diffusion of cohabitation is underway in Italy. Furthermore, we have hypothesised that the delay of this phenomenon, if we compare Italy to other western countries, has been affected by the conditioning of the cultural generational context of the parents. Although the empirical results obtained are consistent with such an hypothesis, in order to test it rigorously more updated and detailed data are necessary. The new survey on "Family and social subjects" currently conducted by ISTAT will be particularly useful on this subject. This survey will considerably enrich the information gathered up to now in Italy on cohabitation, since it takes into account both the behaviour and the values and expectations of both children and parents.

It will be also interesting to evaluate to which extent the explanation of the delay of the diffusion of the cohabitations is generalizable to other western countries characterized by strong family ties. In Spain, for example, the timing of the diffusion of cohabitation is similar to the Italian case. In this country too the delay could be ascribed more to the "still socially deviant status of cohabitation" (Baizan et al. 2003) rather than a limited interest of the youth towards this kind of first union. In Spain, indeed, among younger generations, there is a wider acceptance toward the formation of unmarried couples which, however, is hardly reflected in their actual behaviour. Moreover, similar to Italy, it is the intergenerational solidarity within the Spanish family, more than the feeble welfare politics, which enables the youth to face the risks and uncertainties of the socio-economic system in which he/she lives (Moreno Minguez 2003, Holdsworth and Irazoqui Solda 2001). Therefore, the hypothesis that the soft and delayed diffusion is a consequence of the convenience of the children to avoid choices which are openly clashing with the values of the parents could also account for the Spanish case (Note 10).

Besides the greater value attached to the family, in Italy (but not only), marriage continues to be a very popular choice even among the younger generations. At least for the Italian case, indeed, the diffusion of informal unions seems to be more likely an answer to the need for greater flexibility in the early stages of the transition to adulthood (Note 11) than a questioning of the role of marriage.

The continuity of the strong ties and the importance of marriage suggest that cohabitation, although quickly increasing in the near future, will keep on remaining for a while mainly a prelude to marriage. Cohabitants will continue to live in close proximity to their parents and will continue to have an intense material and immaterial exchange with them. 


\section{Acknowledgments}

We are grateful to Gianpiero Dalla Zuanna, Pier Paolo Viazzo, Aat Liefbroer and the two anonymous referees of Demographic Research for their very useful comments on earlier versions of this paper. 


\section{Notes}

1. "Public transfers for the young (for health, social assistance, and particularly for education) are among the lowest in Europe. Whatever is not given by the community must be supplied, one way or the other, by the family, which fills the gap" (Livi Bacci 2001).

2. Several studies have indeed shown how penalizing a lack of parental help can be for the Italian youth in terms of realization of important personal objectives, of their professional career, and in the purchase of a house (Dalla Zuanna 2001).

3. For further information see www.istitutoiard.it.

4. The roots of the new forms of household formation can be identified in the 1960s, and in particular "in the marked shift in values that occurred during that decade. They linked the demographic changes to (i) the accentuation of individual autonomy in ethical, moral and political spheres, (ii) to the concomitant rejection of all forms of institutional controls and authority, and (iii) to the rise of expressive values" (Surkyn and Lesthaeghe 2002).

5. In literature, the Italian society is generally portrayed as having a less favourable attitude towards alternative unions to marriage if compared to other western countries. This limited social approval is often linked to a greater cultural traditionalism towards family and marriage (see for example the relatively late introduction of the law on divorce) matched with the strong presence of the Catholic Church (see, among others, Ginsborg 1989, 1998; Goody 2000; Nazio, Blossfeld 2003). We may therefore believe that the divergence between such a limited social approval and the large favourable opinion of the youth toward cohabitation (as shown in table 2), was wider than in other western countries. Nevertheless it is important to keep in mind that the core of our hypothesis is indeed another. That is - even if the divergence in other western countries between the youth's attitudes and the values of their elders were equal to that observed in Italy - the strong ties between parents and children (with the implications described in section 3) and the close residential proximity (even when the youth has already left the parental home), makes the possibility of a "tolerant indifference" harder in Italy. That "tolerant indifference" which enables the European youth in the weak family ties area to freely make choices, even though these are not shared by their parents (Beck 1997).

6. It is the case when the attitudes of the parents affect the behaviour of their children. It must be kept in mind that there is a possible reciprocal causation between attitudes and behaviour. If the traditional attitudes among the older 
generations might limit the behaviour of the younger, on the other hand their attitudes may also liberalize as the non traditional behaviour becomes more common.

7. This is particularly true for first unions: the choice to cohabit "is the step previous to marriage ( 2 cases out of 3 ) and if it replaces it, it is because at least one of the partners was already married" (De Sandre 2000; see also Castiglioni 1999).

8. Traditionally the "fuitina" (elopement) is the kidnapping of a young woman by her boyfriend in order to oblige her family to give consent to marriage. However, this is often carried out in complicity with the two families in order to avoid the expensive costs of a wedding party. Indeed, it is usually followed by a frugal celebration of the marriage.

9. One could object that the level of education of the father can also be considered a good proxy of the material resources of the parental family. However, if this is the prevailing interpretation of the variable we would expect an opposite effect on cohabitation, since the material resources of the parental family tend, if anything, to favour a longer stay in the parental family (indeed the material convenience to leave it decreases, in particular "in a familistic oriented society, the rising of real income hampers - rather than favours - the early departure of children", Dalla Zuanna 2001; see also Barbagli et al. 2003; Cavalli, De Lillo 1993) or a direct marriage (which, particularly in Italy, requires greater financial support from the family of origin than cohabitation). Indeed, from a mere economic perspective values, attitudes, cultural opening up, and so on being equal - the choice to cohabit can be seen as a rational decision "in the face of uncertainty, insecurity, unemployment and socio-economic disadvantage, just as it was in times past. In effect a poor person's marriage" (Kiernan 2002b; See also Oppenheimer 1988, 2003; Mills, Blossfeld 2003).

10. It would be interesting to extend the discussion to the USA too for example for some similar aspects to the weak family ties area ( "practical family support for the transition to adulthood is not as widely available as in Italy", Cook, Furstenberg 2001) but where cohabitation, although widespread, "is not normatively encouraged" (ibidem), and to Japan "in which lineal parent-children relationships are regarded as more important than husband-wife (or man-woman) relationships probably, having its roots in the stem family system in the pre-modern Japan [...]. Traditional familism seems to bind even the mind and behaviour of young people in the contemporary Japan" (Atoh 2001).

11. "There is empirical evidence that youth in all countries are clearly exposed to more uncertainty in the course of globalization [...]. High degrees of economic 
uncertainty will inhibit youth to make long-term binding commitments such as partnerships, and particularly marriage" (Mills and Blossfeld, 2003; see also Oppenheimer, 1988). 


\section{References}

Atoh M. (2001). "Why are cohabitation and extra-marital births so few in Japan?", Paper presented at the EURESCO conference on The second Demographic Transition in Europe, Bad Herrenalb, Germany, 23-28 June 2001.

Baizán P., Aassve A., Billari F. (2003). "Cohabitation, marriage, first birth: The interrelationship of family formation events in Spain", European Journal of Population, 19 (2).

Barbagli M., Castiglioni M., Dalla Zuanna G. (2003). Fare famiglia in Italia. Un secolo di cambiamenti, Bologna: il Mulino.

Barbagli M., Kertzer D.I. (1992). (eds.) Storia della famiglia italiana. 1750-1950, Bologna: il Mulino.

Barbagli M., Saraceno C. (1997). (eds), Lo stato delle famiglie in Italia, Bologna: il Mulino.

Barbagli M. (1997). "Family and kinship in Italy", in Gullestad M., Segalen M. (eds.) Family and Kinship in Europe, pp. 33-48, London: Pinter.

Beck U. (1997). "Demokratisierung der Familie", in Beck U. (ed.) Kinderder der Freiheit, Frankfurt a.M.: Suhrkamp.

Becker G. (1981). A treatise on the family, Cambridge, Usa: Harvard University Press.

Billari F., Rosina A. (2004). "Italian latest-late transition to adulthood: an exploration of its consequences on fertility", Genus, LX (1).

Billari F.C., Castiglioni M., Castro Martin T., Michelin F., Ongaro F. (2000). "Household and Union Formation in a Mediterranean Fashion: Italy and Spain". FFS Flagship Conference, Brussels, 29-31 May 2000.

Bloom A. (1994). "Marriage and Cohabitation in a Changing Society: Experience of Norwegian Men and Women Born in 1945 and 1960", European Journal of Population, 10: 143-173.

Breschi M., Livi Bacci M. (2003). (eds.). La bassa fecondità italiana tra costruzioni economiche e cambio di valori, Udine: Forum.

Brienza G. (2001). Famiglia e politiche familiari in Italia, Roma: Carocci.

Buzzi C., Cavalli A., de Lillo A. (2002) (eds). Giovani del nuovo secolo, Bologna: il Mulino 
Castiglioni M. (1999). "Analisi differenziale della nuzialità", in De Sandre P., Pinnelli A., Santini A. (1999) (eds).

Castiglioni M., Dalla Zuanna G. (1994). "Innovation and Tradition: Reproductive and Marital Behaviour in Italy in the 1970s and 1980s", European Journal of Population, 10: 107-141.

Cavalli A., De Lillo A. (1993). (eds). Giovani anni '90. Terzo rapporto Iard sulla condizione giovanile in Italia, Bologna: Il Mulino.

Crouch C. (1999). Social Change in Western Europe, New York: Oxford University Press,.

Cook T.D., Furstenberg Jr F.F. (2001). "Juggling School, Work and Family: The Transition to adulthood in Italy, Sweden, Germany and the United States", WP01-01.

Dalla Zuanna G. (2001). "The banquet of Aeolus. A familistic interpretation of Italy's lowest low fertility", Demographic Research, 4 (5).

De Beer J., Corijn M., Deven F. (2000). "Summary and conclusions", in De Beer J., Deven F. (eds). Diversity in Family Formation: The $2^{\text {nd }}$ Demographic Transition in Belgium and the Nertherlands, Dordrecht: Kluwer.

Derosas R. (2002). "Si sposi chi può, resti chi deve: matrimonio e relazioni familiari nella Venezia di metà Ottocento", Popolazione e Storia, n.1, pp. 35-67.

De Sandre P. (1997). "La formazione di nuove famiglie", in Barbagli M., Saraceno C. (1997) (eds).

De Sandre P. (2000). "Patterns of fertility in Italy and factors of its decline", Genus, LVI, 1-2, 2000.

De Sandre P., Ongaro F., Rettaroli R., Salvini S. (1997). (eds). Matrimonio e figli: tra rinvio e rinuncia, Bologna: il Mulino.

De Sandre P., Pinnelli A., Santini A. (1999) (eds). Nuzialità e fecondità in trasformazione: percorsi e fattori del cambiamento, Bologna: il Mulino.

Easterlin R., Crimmins E. (1991). "Private materialism, persona self-fulfilment, family life and public interest: The nature, effects, and causes of recent changes in the value of American youth", Public Opinion Quarterly, 55:499-533.

Giddens A. (1990). The Consequences of Modernity, Cambridge: Polity Press. 
Giddens A. (1999). Runaway World. How Globalization is Reshaping our Lives, London: Profile Books.

Ginsborg P. (1989). Storia dell'Italia dal dopoguerra ad oggi, Torino: Einaudi.

Ginsborg P. (1998). L'Italia del tempo presente, Torino: Einaudi.

Goody J. (2000). The European Family. An Historico-Anthropological Essay, Oxford: Basil Blackwell.

Gubert R. (2000). La via italiana alla postmodernità. Verso una nuova architettura dei valori, Milano: FrancoAngeli.

Hoem J.M. (1986). "The impact of education on modern family union initiation", European Journal of Population, 2, 113-133.

Hoem B. (1995). "Sweden", in Blossfeld H.P. (ed.) The new Role of Women. Family Formation in Modern Societies, pp. 35-55. Boulder, CO: Westview.

Holdsworth C. and Irazoqui Solda M. (2002). "First housing moves in Spain: an analysis of leaving home and first housing acquisition", European Journal of Population, 18: 1-19.

ISTAT (2000). Le strutture familiari, Collana Informazioni, N.17, Roma.

ISTAT (2003). Rapporto Annuale 2002, Roma.

Kiernan K. (1999). "Cohabitation in Western Europe”, Population Trends, 96: 25-32.

Kiernan K. (2000). "Cohabitation in Western Europe: Trends, Issues and Implications", in Just Living Together: Implications of Cohabitation for Children, Families, and Social Policy, Population Research Institute, Pennsylvania State University, 2000 .

Kiernan K. (2002a). "The state of European unions: an analysis of partnership formation and dissolution", in Macura M., Beets G. (eds.) Dynamics of fertility and partnership in Europe. Insights and lessons from comparative research. Volume I. United Nations.

Kiernan K. (2002b). "Unmarried cohabitation and parenthood: here to stay? European perspectives", paper presented at the Conference on Public Policy and the Future of the Family, October $25^{\text {th }} 2002$.

Lesthaeghe R. (1995). "The second demographic transition in Western countries: an interpretation", in Oppenheim Mason K., Jensen A-M. (eds.) Gender and Family Changes in Industrialized Countries, Oxford: Clarendon Press. 
Lesthaeghe R., Moors G. (2000). "Recent trends in Fertility and Household Formation in the Industrialised World", Interuniversity papers in demography, Interface demography, Department of Social Research (SOCO) Vrjie University Brussels.

Liefbroer A. (1999). " From youth to adulthood: Understanding changing patterns of family formation from a life course perspective", in van Wissen L.J.G., Dykstra P.A. (eds.) Population Issues: An Interdisciplinary Focus, Plenum Press.

Liefbroer A. (2003). "Transition to adulthood in Europa: empirical results and theorethical considerations", paper prepared for workshop on "Immigration, family and the transition to adulthood: Sweden in the European context", Bergendal, Sweden, May 23-2, 2003.

Livi Bacci M., Salvini S. (2000). "Trop de famille et trop peu d'enfants: la fécondité en Italie depuis 1960", Les Cahiers québécois de démographie, 29 (2).

Livi Bacci M. (2001). “Too Few Children and Too Much Family”, Dedalus, 130, 3 : 139-155.

Macura M., Beets G., Burkimsher M. (2002). Fertility and partnership: why the FFS and what did we learn from it?, in Macura M., Beets G. (eds.) Dynamics of fertility and partnership in Europe. Insights and lessons from comparative research. Volume I. United Nations.

Macura M., Sternberg Y.M., Garcia J.L. (unedited draft) Europe's fertility and partnership: selected developments during the last ten years.

Mason K.O., Jensen A.M. (1995). (eds.) Gender and Family Change in Industrialized Societies, Oxford: Clarendon Press.

Micheli G.A. (1997). "Spezzare il retaggio, forse assecondarlo. Intrecci tra dinamiche di povertà e modelli familiari", Polis, 2.

Micheli G.A. (2000). "Kinship, family and social network: the anthropological embedment of fertility change in Southern Europe", Demographic Research, 3.

Mills M. (2000). The Transformation of Partnership. Canada, the Netherlands, and the Russia Federation in the Age of Modernity, Amsterdam: Thela Thesis.

Mills M., Blossfeld H.P. (2003). "Globalization, uncertainty and changes in early life courses", Globalife research project, February 2003.

Moreno Mìnguez A. (2003). “ The Late Emancipation of Spanish Youth: Keys For Understanding “, Electronic Journal of Sociology, vol. 7. 
Nazio T., Blossfeld H.P. (2003). "The diffusion of cohabitation among young women in West Germany, East Germany and Italy", European Journal of Population, 19 (2).

Ongaro F. (2001). "Transition to adulthood in Italy", in Corijn M., Klizing E. (eds.), Transition to Adulthood in Europe, Dordrecht: Kluwer Academic Publishers.

Oppenheimer V.K. (1988). "A theory of marriage timing" American Journal of Sociology, 94: 563-591.

Oppenheimer V.K. (2003). "Cohabiting and Marriage During Young Men's CareerDevelopment Process", Demography, 40,1, 127-149.

Pinnelli A. (1995). "Woman's Condition, Low Fertility, and Emerging Union Patterns in Europe", in Mason K.O., Jensen A.M. (1995).

Pinnelli A., De Rose A., Di Giulio P., Rosina A. (2002). "Interrelationships between partnership and fertility Behaviour", in Macura M., Beets G., Dynamics of fertility and partnership in Europe. Insights and lessons from comparative research. Volume I. United Nations.

Prinz C. (1995). Cohabiting, Married, Single, England: Avebury.

Reher D.S. (1998). "Family Ties in Western Europe: persistent contrasts", in Population and Development Review, 24.

Rosina A. (2001). "Quest'unione libera non s'ha da fare", paper presented at the conference on La bassa fecondità italiana tra costrizioni economiche e cambio di valori, Florence, 8-9 novembre, 2001.

Rosina A. (2002). "Le prime unioni alternative al matrimonio", Famiglie, mutamenti e politiche sociali. Vol. I, Osservatorio Nazionale sulle famiglie e le politiche locali di sostegno alle responsabilità familiari, Bologna: il Mulino.

Rosina A., Billari F. (2003). "Flessibilità all'entrata in unione: i precursori del cambiamento", in Breschi M., Livi Bacci M. (eds.) La bassa fecondità italiana tra costruzioni economiche e cambio di valori, Udine: Forum.

Rosina A., Fraboni R., Sabbadini L.L. (2003). Diventare uomini e donne in Italia, in Pinnelli A., Racioppi F., Retttaroli R. (eds.) Genere e demografia, Bologna: il Mulino.

Sabbadini L.L. (1991). "Le convivenze prematrimoniali", in Menniti A. (ed.) Le famiglie italiane negli anni '80, Irp, Collana Monografie, 2. 
Saraceno C. (1994). "The ambivalent familism of Italian welfare state", Social Politics, $1,60-82$.

Schoenmaeckers A. C., Lodewijckx E. (1999). "Demographic Behaviour in Europe: Some Results from FFS Country Reports and Suggestions for Further Research", European Journal of Population, 15: 207-240.

Seltzer J.A. (2000). "Families formed outside of marriage", Journal of Marriage and the Family, 62: 1247-68.

Sgritta (2002). "La transizione all'età adulta: la sindrome del ritardo", Famiglie, mutamenti e politiche sociali. Vol. I, Osservatorio Nazionale sulle famiglie e le politiche locali di sostegno alle responsabilità familiari, Bologna: il Mulino.

Surkyn J., Lesthaeghe R. (2002). "Values Orientations and the Second Demographic Transition (SDT) in northern, western and southern Europe: An update", Interuniversity papers in demography, Interface demography, Department of Social Research (SOCO), Vrjie University Brussels.

Tomassini C., Wolf D., Rosina A. (2003). " Parental housing assistance and parentchild proximity in Italy", Journal of Marriage and Family, 65 (3).

Toulemon L. (1997). "Cohabitation is here to stay", Population: An English selection, Vol. 9, pp. 11-46.

Viazzo P.P. (2003). "What's so special about the Mediterranean? Thirty years of research on household and family in Italy", Continuity and Change 18 (1), 111137.

Van de Kaa D.J. (1987). “Europe's Second Demographic Transition”, Population Bulletin, N.42. 